Joanna Cukras-Stelagowska*

Toruń

\title{
Cheder i melamed we wspomnieniach młodzieży żydowskiej okresu międzywojennego
}

Edukacja i wykształcenie w kulturze żydowskiej to cnota moralna, nakaz społeczny oraz zinternalizowana wartość dla życia rodzinnego, a także cel największych aspiracji rodzicielskich. Szczególną wagę przykładano do wychowania chłopców. Wedle judaizmu każdy mężczyzna powinien przez całe życie zgłębiać wiedzę, jak również dążyć do doskonałości w opanowaniu i komentowaniu tekstów religijnych. Wybitni znawcy kultury żydowskiej, Arthur Hertzberg i Aron Hirt-Manheimer, wskazują, że: „uczenie się Tory jest najwyższą żydowską wartością, ponieważ w tym momencie Żyd jest tak blisko, jak tylko możliwe, Boskiego objawienia"".

Niniejszy artykuł stanowi próbę stworzenia zbiorowego portretu chederów oraz pracujących w nich nauczycieli w okresie dwudziestolecia międzywojennego. Edukacja w chederze stanowiła niezwykle ważny etap na drodze dorastania żydowskich chłopców, decydujący o dalszych trajektoriach edukacyjnych i zawodowych, przygotowujący do pełnego uczestnictwa we wspólnocie. Bazą dla analizy tego zagadnienia są prace historyków, a także

* Dr Joanna Cukras-Stelągowska jest adiunktem w Wydziale Nauk Pedagogicznych Uniwersytetu Mikołaja Kopernika w Toruniu, w Katedrze Teorii Wychowania. Adres: Wydział Nauk Pedagogicznych UMK, ul. Lwowska 1, 87-100 Toruń; e-mail: joanstel@umk.pl.

${ }^{1}$ Arthur Hertzberg, Aron Hirt-Manheimer, Żydzi. Istota i charakter narodu (Warszawa: Mada, 2001), 97-98. 
materiały pamiętnikarskie: z zastosowaniem metody egzemplifikacji, ilustrującej i uzasadniającej problemy badawcze przykładami z autobiografii, oraz częściowo metody typologicznej, której celem jest ustalanie typów osobowości, postaw czy zachowań w różnych zbiorowościach ${ }^{2}$. Jest to jakościowa analiza materiałów, zmierzająca do odpowiedzi na następujące pytania: Czy pamiętniki potwierdzają powszechną opinię o niskim poziomie kształcenia w chederach okresu międzywojnia? W jakim stopniu doszło do dewaluacji tej formy edukacji religijnej? Czy stworzony przez młodych Żydów wizerunek mełameda jest jednorodny i jednoznacznie negatywny? Metoda biograficzna jest często krytykowana za brak reprezentatywności, subiektywizm i możliwe konfabulacje autorów, jak również brak jednorodności materiałów. Z wszystkim tymi uwagami należy się zgodzić. Jej walory w postaci funkcji ilustracyjnej, heurystycznej oraz uwrażliwiającej zdają się jednak górować nad zarzutami ${ }^{3}$.

\section{System żydowskiej edukacji religijnej}

System obowiązkowej religijnej edukacji żydowskiej należy do najstarszych tradycji edukacyjnych ${ }^{4}$. W wiekach nowożytnych ukształtował się dwustopniowy model nauczania religijnego: najpierw wszyscy chłopcy przystępowali do chederów (prywatnych lub tzw. Talmud-Tor, czyli bezpłatnych szkółek, utrzymywanych przez gminy żydowskie), a następnie po ukończeniu trzynastego roku życia i konfirmacji (bar-micwie) zdolniejsi uczniowie kontynuowali naukę w jesziwach (uczelniach talmudycznych). Pozostali przygotowywali się do rozpoczęcia pracy i założenia rodziny. Nadal jednak mogli zgłębiać wiedzę religijną w otwartych dlań domach nauki (bejt ha-

2 Por. Jan Szczepański, Odmiany czasu teraźniejszego (Warszawa: Książka i Wiedza, 1973), 641-642.

3 Anna Giza, „Biografia jako fakt empiryczny i jako kategoria teoretyczna”, w: Metoda biograficzna $w$ socjologii, red. Jan Włodarek, Marek Ziółkowski (Warszawa-Poznań: Państwowe Wydawnictwo Naukowe, 1990), 48-49.

${ }^{4}$ Już w pierwszej połowie I w. p.n.e. uczony Szymon ben Szetach zainicjował zakładanie przy synagogach bądź w ich pobliżu szkół publicznych zwanych be(j)t ha-sefer, w których dzieci od 6-7 roku życia uczyły się czytania i pisania po hebrajsku oraz studiowały z nauczycielem Pięcioksiąg. Kolejnym stopniem edukacji były szkoły be(j)t ha-midrasz uczące Prawa Pisanego i Prawa Ustnego. Por. Zofia Borzymińska, Szkolnictwo żydowskie w Warszawie 1831-1870 (Warszawa: Żydowski Instytut Historyczny - Instytut Naukowo-Badawczy, 1994), 8-9. 
midraszach), mieszczących się przy synagogach ${ }^{5}$. Marzeniem większości rodziców było ukończenie przez syna z wynikiem pozytywnym akademii talmudycznej i otrzymanie certyfikatu rabinackiego (smichy) ${ }^{6}$.

Chedery (z hebr. „izba”, ,pokój”) stanowily pierwszy etap edukacyjny. Uczyły się w nich dzieci w wieku od około 4. lub 5. do 12. roku życia. Zgodnie z tradycją naukę w nich podejmowali głównie chłopcy. Dziewczynki rzadko uczęszczały do koedukacyjnych chederów, najczęściej z pomocą rodziców uczyły się w domu, a w bogatszych rodzinach zatrudniano dla nich prywatnych korepetytorów ${ }^{7}$. Zapisanie pięcioletniego chłopca do chederu należało do obowiązków ojca, z którym nauczyciel chederu zawierał umowę. Rodzice uiszczali comiesięczne opłaty, po części mieli zatem wpływ na jakość i program nauczania ${ }^{8}$.

Proces dydaktyczny w szkole religijnej podzielony był na trzy dwuletnie etapy ${ }^{9}$. Młodzi adepci musieli przede wszystkim nauczyć się hebrajskiego i opanować pamięciowo fragmenty Tory, dopiero na trzecim poziomie włączano bardziej intelektualną analizę Talmudu. Zajęcia trwały do późnych godzin wieczornych. Historyk Rafał Żebrowski pisze, że:

dzień nauki w miesiącach letnich zaczynał się bezpośrednio po modłach porannych (szacharit), w czasie surowej zimy rano lekcje nie odbywały się albo

${ }^{5} \mathrm{Na}$ temat dwustopniowego żydowskiego systemu szkolnictwa religijnego pisałam również: Joanna Cukras-Stelągowska, „Od chederu do jesziwy w polskiej diasporze - dwustopniowy system żydowskiego szkolnictwa religijnego i jego współczesne transformacje”, Paedagogia Christiana 23 (2009): 121-135.

${ }^{6}$ Por. Jan Hellwig, „Edukacja młodzieży żydowskiej w XIX w. w Poznaniu”, w: Rola mniejszości narodowych w kulturze i oświacie polskiej w latach 1700-1939, red. Aleksandra Bilewicz, Stefania Walasek (Wrocław: Wydawnictwo Uniwersytetu Wrocławskiego, 1998), 121.

7 Początki zorganizowanego systemu szkół religijnych dla dziewcząt wiążą się z powstaniem ruchu Bejs Jakow. Założycielką pierwszej szkoły żeńskiej na ziemiach polskich była Sara Szenirer (w 1917 roku w Krakowie). Zob. np. Joanna Lisek, „Sara Szenirer - Matka Bejs Jakow", Cwiszn 2/3 (2014): 67.

${ }^{8}$ Hellwig, ,Edukacja”, 120.

9 Pierwszy dwuletni kurs obejmował czytanie w języku hebrajskim oparte na modlitewniku. Druga kategoria (trzyletnia) obejmowała naukę pamięciową Tory z komentarzami Raszi (skrót od rabbi Szlomo Icchaki z Troyes), naukę etyki oraz zasad dobrego wychowania. Mełamed każdego dnia czytał fragment oryginału Tory, a następnie podawał thumaczenie danego fragmentu w języku jidysz (opierał się na przekładzie wydanego na początku XVII wieku podręcznika Beer-Mosze Mojżesza Sertelsa). W trzeciej kategorii dziewięcioletni chłopcy zajmowali się przez kolejne dwa lata analizą Talmudu (również z komentarzami Raszi). Por. Zygmunt Hoffman, „Od chederu do jesziwy”, Kalendarz Żydowski (1985/86): 84. 
dzieci udawały się wraz z mełamedem do synagogi. Między godziną 10-11-tą była przerwa obiadowa, zaś ok. 14-tej uczniowie spożywali podwieczorek, na który szli do domu. Po powrocie uczyli się dalej, aż do wieczornych modłów (maariw), w których często uczestniczyli wraz z mełamedem, i dopiero po zakończeniu modłów rozchodzili się do domów ${ }^{10}$.

Chłopcy spędzali zatem w chederze niemal cały dzień, jadali wspólnie posiłki, razem obchodzili najważniejsze żydowskie święta. Dzieci dzielono na kilka grup. Część z nich uczyła się pod kierunkiem mełameda bądź w dużych chederach także z pomocnikiem nauczyciela (belfrem), inne w tym czasie bawiły się w ciszy. Zabawa musiała mieć zawsze charakter dydaktyczny i polegała głównie na wynajdowaniu odpowiednich liter w tekstach modlitewnika, Tory oraz Talmudu ${ }^{11}$. Przy tym z uwagi na dużą liczbę dzieci ważne było, aby zabawa była zaplanowana i spokojna. Kreatywne dzieci znajdowały różne sposoby walki ze znużeniem. Znana żydowska etnograf Regina Lilientalowa odnotowała: „Najczęściej nie ruszając się z miejsca, chłopcy urozmaicają sobie czas jak mogą: bądź składają papier w różne kształty, bądź grają w «Iks-miks» lub inne figury kreślą kredą na stole, bądź bezwiednie stosują figlarne środki mnemotechniczne, utrwalają sobie w pamięci nabywane wiadomości”'12.

\section{Próby reform chederów}

Przez wieki ten dwustopniowy system nauczania cieszył się dużym uznaniem wśród Żydów. Jednak wraz z postępem cywilizacyjnym, rozwojem żydowskiego oświecenia (haskali), procesami asymilacyjnymi w diasporze, a następnie modernizacją, ulegał stopniowym (aczkolwiek dość powolnym) przemianom i poddawany był coraz silniejszej krytyce ${ }^{13}$.

10 Rafał Żebrowski, „Polski Słownik Judaistyczny”, hasło: „Cheder”, http://www.jhi.pl/ psj/ (dostęp: 15.11.2017).

${ }^{11}$ Hellwig, „Edukacja”, 120.

12 Regina Lilientalowa, Dziecko żydowskie (Warszawa: Stowarzyszenie Midrasz, 2007), 89.

${ }^{13}$ Definiując procesy sekularyzacyjne, badacze wskazują na okres haskali. Wówczas w kulturze żydowskiej pojawiły się możliwe nowe identyfikacje budowane w oparciu o nowoczesny europejski styl życia, rozwój nauk świeckich oraz oświatę niereligijną, a także idee asymilacyjne wobec kultury dominującej. Judaizm rozumiany jako religia przestał być koniecznym wyznacznikiem żydowskości. Por. Waldemar Szczerbiński, „Charakterystyka kultury żydowskiej w Izraelu i przejawy jej sekularyzacji”, Teologia i Człowiek 27 (2014): 84; Jonathan 
Działo się tak również na ziemiach polskich. Wymykające się kontroli prywatne szkoły religijne wymagały radykalnej naprawy. W okresie zaborów próbowano przyciągać społeczność żydowską do szkół rządowych ${ }^{14}$. Jak podaje Zofia Borzymińska, zdecydowana większość Żydów z Królestwa Polskiego pozostawała jednak wierna tradycyjnej edukacji religijnej - w drugiej połowie XIX wieku nadal $90 \%$ dzieci wyznania mojżeszowego uczyło się w chederach ${ }^{15}$. Zygmunt Hoffman wyjaśnia, że:

oświata świecka dekretowana odgórnie masom społecznie nierozbudzonym, zamkniętym od wieków w kręgu średniowiecznej dogmatyki religijnej nie budziła zaufania. Natomiast ciężar utrzymywania tych szkół spadał na żydowskiego podatnika, chociaż nie uznawał je za szkoły żydowskie ${ }^{16}$.

Należy podkreślić, że żydowscy reformatorzy również uznawali chedery za synonim zacofania społecznego. W tych kręgach pojawiało się wiele idei asymilatorskich w zakresie szkolnictwa. Na uwagę zasługuje tygodnik Jutrzenka, jedyne czasopismo żydowskie wydawane w języku polskim, które ukazywało się na ziemiach Królestwa Polskiego w latach 1861-1863 (wy-

Webber, „Współczesne tożsamości żydowskie”, w: Sytuacja mniejszościowa i tożsamość, red. Zdzisław Mach, Andrzej Paluch (Kraków: Uniwersytet Jagielloński, 1992), 144-145.

${ }^{14}$ W 1820 roku Kajetan Koźmian po wizytacji chederów i bardzo negatywnej ich ocenie zgłosił projekt utworzenia pierwszych szkół elementarnych dla dzieci żydowskich w Królestwie Polskim. Rządowa Komisja Wyznań Religijnych i Oświaty Publicznej wyznaczyła również organizatora szkół żydowskich - Jakuba Tugendhola. W tym samym roku ogłosił on powstanie pierwszych trzech szkół elementarnych dla Żydów w Warszawie. Por. Adam Winiarz, „Sprawa rządowego szkolnictwa elementarnego dla dzieci żydowskich w Księstwie Warszawskim i Królestwie Polskim (1807-1831)", w: Studia o szkolnictwie i oświacie mniejszości narodowych w XIX i XX wieku, red. Stefania Walasek (Wrocław: Wydawnictwo Uniwersytetu Wrocławskiego, 1994), 9-10.

${ }^{15}$ Borzymińska, Szkolnictwo, 33. W latach trzydziestych XIX w. młodzież żydowska stanowiła zaledwie 3,5\% ogółu uczniów szkół publicznych Królestwa. Zdaniem Borzymińskiej, działo się tak z kilku powodów. Po pierwsze, zamknięte rewiry żydowskie często w naturalny sposób ograniczały korzystanie z placówek poza nimi; po drugie, trudno było pogodzić naukę w szkole świeckiej z wymogami religijnymi; w grę wchodziła również kwestia konfliktów pomiędzy uczniami różnych wyznań; poza tym nadal silna była niechęć bardziej „zachowawczej” części społeczności żydowskiej wobec osób posyłających dzieci do szkół ogólnych. Do elementarnych szkół państwowych chodziły głównie dzieci wywodzące się z kręgów uboższych zwolenników oświecenia, zamożniejsi Żydzi woleli zatrudniać prywatnych korepetytorów. Tamże, 94-95.

${ }^{16}$ Hoffman, „Od chederu”, 86. 
dano 120 numerów) ${ }^{17}$. Jutrzenka kładła nacisk na rozbudowę elementarnego szkolnictwa żydowskiego i zastąpienia nim skostniałych chederów ${ }^{18}$. Postulowała „nowoczesny model wychowania opartego na zasadzie zachowania i utrzymania tożsamości religijnej, ale także zmierzającego do maksymalnej integracji ze społeczeństwem polskim" "19. W późniejszym okresie myśl $J u$ trzenki kontynuowało czasopismo Izraelita (1866-1915), stanowiące „trybunę środowisk «postępowych», propagując kulturowe i społeczne zbliżenie Żydów z Polakami i jednocześnie stojąc na straży żydowskiej religii”"20.

Na przełomie XIX i XX wieku dalej dyskutowano nad kwestią kwalifikacji nauczycieli chederów, postulowano wprowadzenie wymogu certyfikatu, włączenia do programu nauczania języka urzędowego oraz zsynchronizowania kalendarza chederu z ogólnym systemem edukacji. Ponadto dalsze procesy modernizacji, asymilacji (a także nurt przeciwny - rozwój żydowskiej myśli narodowej), doprowadziły do istotnych zmian w światopoglądzie lokalnych społeczności żydowskich. Większa liczba rodzin chciała edukacji dzieci w bardziej nowoczesnych szkołach żydowskich (nauczających także przedmiotów świeckich) lub w placówkach publicznych (otwierających możliwości kształcenia na wyższych etapach edukacji w systemie państwowym oraz zdobycia zawodu). Pomimo tych nowych trendów społecznych chedery nadal pozostawały centralnym ogniwem żydowskiego systemu edukacji (zwłaszcza w społeczności chasydzkiej) ${ }^{21}$.

W II Rzeczpospolitej po wprowadzeniu powszechnego obowiązku szkolnego w 1919 roku na poziomie elementarnym dzieci żydowskie obowiązywała nauka w świeckich szkołach państwowych lub żydowskich szkołach prywatnych, realizujących jednocześnie program nauczania z zakresu szkół powszechnych. Tradycyjne szkółki religijne również musiały wprowadzić przedmioty świeckie, aby możliwe było realizowanie w nich obowiąz-

${ }_{17}$ Naczelnym redaktorem Jutrzenki był Daniel Neufeld - nauczyciel, pedagog, pisarz i publicysta. Zob. Barbara Daniłowicz, ,Jutrzenka - tygodnik dla Izraelitów”, w: Studia o szkolnictwie i oświacie mniejszości narodowych w XIX i XX wieku, red. Stefania Walasek (Wrocław: Wydawnictwo Uniwersytetu Wrocławskiego, 1994), 23-33.

${ }_{18}$ Nowe szkoły z polskim jako językiem wykładowym miały mieć profil handlowy oraz nauczać języka niemieckiego i hebrajskiego. Tamże, 34.

19 Tamże, 26.

${ }^{20}$ Założycielem oraz najdłużej kierującym redaktorem Izraelity był Samuel H. Pelty. Zob. Agnieszka Jagodzińska, Marcin Wodziński, Izraelita, 1866-1915. Wybór źródet (Kraków: Wydawnictwo Austeria, 2015), 101.

${ }^{21}$ Por. Mordechai Zalkin, „Heder”, http://www.yivoencyclopedia.org/article.aspx/Heder\#id0elyai (dostęp 30.11.2017). 
ku szkolnego. W sferze żydowskiego życia społecznego uwidoczniły się jeszcze silniejsze prądy sekularyzacyjne, powstała bogata sieć prywatnych szkół odwołujących się do różnych ideologii politycznych (z żydowskim lub hebrajskim językiem wykładowym oraz utrakwistyczne). Środowiska ortodoksyjne starały się bronić tradycji ze wszech miar, ale niektórzy liderzy religijni byli świadomi, że w tym celu należy zezwolić na włączenie w obręb edukacji religijnej nowych treści, a przede wszystkim poprawić jakość kształcenia w chederach ${ }^{22}$.

W tym samym roku powołano Centralną Organizację Oświatową „Chorew”, podległą partii ortodoksyjnej Agudas Israel, która rozpoczęła akcję propagującą reformę wśród żydowskiej społeczności. W chederach nowego typu na przedmioty religijne wyznaczono od 27 do 37 godzin tygodniowo, zaś na przedmioty świeckie 12 godzin (język polski, historię, geografię, przyrodę, arytmetykę, geometrię, rysunek, zajęcia praktyczne, śpiew, wychowanie fizyczne). Nauka w nich miała trwać 8 lat (począwszy od 6 roku życia). Należało wprowadzić podział na klasy, ustalić liczbę godzin lekcyjnych, stworzyć plany lekcji, wzbogacić wyposażenie placówek. Zwolnienie uczniów chederów reformowanych z obowiązku nauki w szkołach publicznych oficjalnie nastąpiło w 1922 roku $^{23}$. Niektóre placówki poważnie traktowały zalecenia władz polskich. Z dokumentów prywatnej ortodoksyjnej szkoły Isoda Tora (Podstawy Tory) w Płocku (1921-1939) dowiadujemy się, że w siatce godzin znalazły się przedmioty świeckie, natomiast aby zostać nauczycielem w tej szkole, trzeba było posiadać co najmniej świadectwo dojrzałości, a także mieć ukończone kursy kwalifikacyjne. Dodatkowymi warunkami było obywatelstwo polskie oraz wyznawanie religii mojżeszowej ${ }^{24}$.

${ }^{22}$ Rafał Żebrowski, Dzieje Żydów w Polsce. 1918-1939. Wybór tekstów źródłowych (Warszawa: Żydowski Instytut Historyczny, 1993), 93.

${ }_{23}$ Stanisław Mauersberg, Szkolnictwo powszechne dla mniejszości narodowych w Polsce w latach 1918-1939 (Wrocław-Warszawa-Kraków: Zakład Narodowy im. Ossolińskich, 1968), 164-172.

${ }^{24}$ Nauczyciele przedmiotów religijnych uzyskiwali potwierdzenie kwalifikacji zawodowych w drodze egzaminów składanych przed rabinem okręgu. Z kolei dyplomy nauczycieli przedmiotów świeckich musiały być poświadczone przez uprawnione jednostki państwowe. Wszyscy nauczyciele byli zobowiązani do podnoszenia kwalifikacji zawodowo-metodycznych. Zob. Andrzej J. Papierowski, ,Żydowskie szkolnictwo religijne na przykładzie działalności prywatnej ortodoksyjnej szkoły Isoda Tora (Podstawy Tory) w Płocku (1921-1939)", Notatki Plockie 4 (2012): 34. 


\section{Chedery i mełamedzi w świetle wspomnień pamiętnikarskich}

Doskonałą ilustracją dla zmian w obrębie szkolnictwa żydowskiego są autobiografie polskiej młodzieży żydowskiej okresu międzywojennego ze zbiorów YIVO Institute for Jewish Research w Nowym Jorku. Cześć z nich znalazła się w zbiorze zredagowanym przez Alinę Całą pt. Ostatnie pokolenie. Autobiografie polskiej młodzieży żydowskiej okresu międzywojennego ze zbiorów YIVO Institute for Jewish Research w Nowym Jorku, w którym zamieszczono i opatrzono krótkim komentarzem dwadzieścia diariuszy polskiej młodzieży żydowskiej, napisanych na konkursy ogłoszone w latach 1932, 1934 i 1939 przez Żydowski Instytut Naukowy JIWO w Wilnie. Piętnaście wspomnień młodzieży żydowskiej zebrał Jeffrey Shandler w Awakening Lives. Autobiographies of Jewish Youth in Poland before Holocaust. Autorami analizowanych wspomnień była młodzież żydowska w wieku 17 -19 lat, wywodząca się z różnych środowisk społecznych, z różnych części Polski w jej przedwojennych granicach ${ }^{25}$. Jednym $z$ dominujących elementów pamięci autobiograficznej „Ostatniego pokolenia” były doświadczenia szkolne, również najwcześniejszy etap edukacji w chederach.

Młodzież w pamiętnikach wykazała bardzo krytyczny stosunek wobec metod wychowania w swoich rodzinach, a także w stosunku do całej tradycji małych społeczności sztetlowskich. Miała bowiem inne autorytety niż jej rodzice, „uciekała do «pionierów», Bundu, młodzieżowych ruchów syjonistycznych" ${ }^{26}$. W większości diariuszy dojrzewanie i edukacja w szkole powszechnej bądź zaangażowanie w organizację młodzieżową różnych żydowskich organizacji politycznych wyznaczyły kres religijności narzuconej przez otoczenie społeczne rodzinne, a przynajmniej przyniosły głęboką refleksję nad jej charakterem. Socjalizacja w grupie rówieśniczej, edukacja formalna w polskich szkołach, migracje w okresie gimnazjalnym do większych ośrodków miejskich spowodowały redefinicje tożsamości społecz-

${ }^{25}$ Uzupełniająco dokonałam kwerendy archiwalnej pamiętników w Centralnym Archiwum Dziejów Narodu Żydowskiego - CAHJP w Jerozolimie (znajdują się tam kopie pamiętników ze zbiorów Archiwum JIWO w Nowym Jorku, dodatkowo 10 diariuszy spisanych w języku polskim, niemieckim, hebrajskim i rosyjskim, wzbogaconych o psychologiczne charakterystyki autorów oraz komentarze dr Henryka Ormiana).

${ }^{26}$ Regina Renz, „Wychowanie w rodzinie żydowskiej w Polsce międzywojennej”, w: Rola mniejszości narodowych w kulturze i oświacie polskiej w latach 1700-1939, red. Aleksandra Bilewicz, Stefania Walasek (Wrocław: Wydawnictwo Uniwersytetu Wrocławskiego, 1998), 253. 
no-kulturowych w stronę najpierw polonizacji, a potem na skutek wzrostu antysemityzmu - w kierunku budowania świeckiej żydowskiej tożsamości narodowej ${ }^{27}$.

W tym okresie przeważająca liczba szkół religijnych nie spełniała nowych wymogów, w obawie przed restrykcjami uchylała się od rejestracji. Chedery zreformowane funkcjonowały przede wszystkim w większych ośrodkach miejskich. Na prowincji nadal dominowały szkoły, które nie prowadziły nauczania przedmiotów świeckich, zatem nie zwalniały uczących się w nich dzieci z obowiązku szkolnego ${ }^{28}$. Twórcy pamiętników z rodzin ortodoksyjnych trafiali zarówno do chederów tradycyjnych, jaki i (rzadziej) do placówek zreformowanych. Po przeanalizowaniu wszystkich biografii w obu opublikowanych zbiorach można zauważyć, że w wypowiedziach autobiograficznych przeważają krótkie wzmianki na temat edukacji w chederach. Autorzy omawiali w swoich wspomnieniach wiele innych wątków (edukację w szkole publicznej, wychowanie rodzinne, przyjaźnie, aktywność polityczną, wybór zawodu). Ponadto nie wszyscy ukończyli cheder, gdyż rodzice często po trudnych naradach rodzinnych - decydowali się przerwać naukę i posłać dziecko do szkoły powszechnej. Zatem ci, którzy rozpoczynali naukę w tradycyjnych szkółkach religijnych, nie zawsze ją kończyli. Bywały także przypadki nawet kilkukrotnych zmian placówek. Byli także tacy autorzy, którzy przyznawali, że nie pamiętają tego wczesnego etapu edukacji (np. „A. Greyno”, ur. 1911, w małym miasteczku koło Kielc) ${ }^{29}$. Bardziej tradycyjni rodzice każdego poranka wysyłali syna do placówki publicznej, po południu zaś na zajęcia w chederze. Rodziny świeckie wybierały prywatne szkoły żydowskie, działające pod auspicjami partii i stowarzyszeń politycznych. Młodzi piszący po polsku, wywodzący się z rodzin zasymilowanych w ogóle nie chodzili do chederów, lecz do szkół powszechnych. Z tych względów do analizy wybrałam niemal całe fragmenty wypowiedzi na temat edukacji

27 Szerzej na ten temat pisałam: Joanna Cukras-Stelągowska, „Biograficzna wspólnota wspomnień «Ostatniego pokolenia» - młodzież żydowska wobec dylematów tożsamościowych”, Paedagogia Christiana 32 (2014): 185-202; Joanna Cukras-Stelągowska, „Upbringing Styles In an Orthodox Jewish Family In the Interwar Period. Autobiographical Contexts", Studienreihe der Polnischen Historischen Mission 2 (2015): 149-168.

${ }^{28}$ W roku 1934/35 zaledwie 1/4 uczniów chederów społecznych i prywatnych była zwolniona z obowiązku szkolnego w szkołach publicznych. Por. Samuel Chmielewski, „Stan szkolnictwa wśród Żydów w Polsce”, Sprawy Narodowościowe 1-2 (1937), cyt. za: Mauersberg, Szkolnictwo, 174-175.

29 „A. Greyno”, ur. 1911, 1934, jidysz, w: Jeffrey Shandler, Awakening Lives. Autobiographies of Jewish Youth in Poland before Holocaust (New Haven: Yale University Press, 2002), 54. 
w chederze wszystkich autorów, którzy doń uczęszczali. W efekcie wyróżniłam trzy egzemplifikacje, które w moim przekonaniu składają się na obraz chederu oraz nauczyciela w nim pracującego.

\section{Egzemplifikacja I}

Chłopiec o pseudonimie „Heniek G.” (ur. w 1912 r. w Warszawie, w rodzinie wielodzietnej) od 5 r. życia uczył się w bezpłatnej Talmud-Torze. W biografii wspomina, że wiele razy uciekał z chederu:

Nie mogłem znieść ani samej nauki, ani sposobu uczenia. Przy stole stał srogi mełamed, trzymał długą pałkę w ręku i walił nią o stół, a my wszyscy (było nas może ze czterdziestu kilku) kiwaliśmy się całym tułowiem i chórem krzyczeliśmy śpiewnym głosem za uderzeniami pały. [...] Gdy mełamed przestał walić w stół, wówczas dopiero zamilkli wszyscy. Nierzadko zdarzało się, że chłopcy zamiast powtarzać bezmyślnie za mełamedem, rozmawiali między sobą o własnych sprawach, albo też po prostu przeklinali rebego. Biada jednak była takiemu, gdy został przez rebego przyłapany! Był katowany tak, że miał sobie do zapamiętania na długie czasy! ${ }^{30}$.

Chłopiec wymyślał różne preteksty, aby nie chodzić do chederu. Wolał spędzać czas z kolegami. Rodzice reagowali gwałtowne na taki brak subordynacji:

Innym razem uparłem się, że już w żaden sposób nie wrócę do chederu, chcę pójść do sklepu zarabiać pieniądze. Wtedy ojciec udawał, że się zgadza na to i zabrał mnie ze sobą na ulicę, mówiąc, że idzie mnie oddać do sklepu. Chętnie poszedłem. Ale gdy przeszliśmy obok chederu, ojciec złapał mnie nagle za barki i zawlókł do chederu. Nie zważał ani na mój płacz, ani na to, że biłem głową o podłogę. Ja znów widząc, że w żaden sposób nie mogę pozbyć się chederu, stałem się bardzo zły na rodziców, a nawet zacząłem przeklinać ojca i wszystkich w ogóle w domu ${ }^{31}$.

30 „Heniek G.”, „Mój pamiętnik”, ur. 1912, Warszawa (1934), j. polski, sygn. 3587, w: Alina Cała, Ostatnie pokolenie. Autobiografie polskiej młodzieży żydowskiej okresu międzywojennego ze zbiorów YIVO Institute for Jewish Research w Nowym Jorku (Warszawa: „Sic!”, 2003), 73 .

31 Tamże, 73-74. 
W wieku 11 lat najstarszy brat zapisał go do szkoły powszechnej, gdzie chłopiec uczył się chętniej. Niestety, później nie miał środków na naukę i już od 14. roku życia pracował jako robotnik.

Młodzieniec o pseudonimie „Zyg. Hor.” urodził się w 1912 roku w Zakopanem. Jego ojciec miał sklep galanteryjny, był Żydem postępowym, ale chciał żeby synowie znali zasady i zwyczaje żydowskie. Jako mały chłopiec „Zyg. Hor.” buntował się ,"przeciw tym próbom zamachu na wolność hasania beztroskiego i nie chciał chodzić do chederu, z którego uciekał z płaczem ${ }^{32}$. $\mathrm{W}$ tej sytuacji rodzice wynajęli najpierw prywatnego nauczyciela religii, a potem zdecydowali się na prywatną szkołę pani Stegmanowej, w której:

mimo lenistwa i niechęci do nauki, mimo wykręcania się od zadań, mimo poprzekreślanych zeszytów, w których stawiałem jakieś iście „kabalistyczne” znaki [zamiast liter], okres tych paru lat spędzonych w tej mojej jedynej szkole należy do najpiękniejszych dni mego wczesnego dzieciństwa ${ }^{33}$.

Chłopiec następnie uczył się w gimnazjum. Niestety, po śmierci matki musiał przerwać naukę i wstąpić na praktykę do sklepu ojca. W późniejszym okresie ukształtowały go kolonie żydowskie, został syjonistą, odszedł zupełnie od identyfikacji religijnej.

Edukację w chederze przerwał również autor używający pseudonimu „EM. TEPA”. Urodzony w 1919 roku w Parczewie, w ubogiej rodzinie rzemieślniczej w środowisku małomiasteczkowej ortodoksji. Jego dzieciństwo przebiegało w cieniu choroby psychicznej matki. Ojciec był podziwianym społecznikiem, Żydem progresywnym. „EM. TEPA” przystąpił do chederu pod naciskiem dziadka, gdyż ojciec chciał dla niego innej edukacji:

Prędko przyzwyczaiłem się do nowych kolegów i do tego żydowskiego nauczyciela, który z początku bardzo na mnie uważał z dwóch względów: po pierwsze, że każdego nowego ucznia przyjmował łagodnie, pod drugie byłem synem radnego [...]. Nowe środowisko nie wywarło na mnie żadnego prawie wrażenia. Dziwię się, że nie zrodził się we mnie bunt przeciwko brudom chederu. Nie buntowałem się przeciw niesprawiedliwości „rebego”, którego ręka jednych głaskała, innych za te same ,przewinienia” biła. Niedługo jednak trwała ta bierność. $Z$ chwilą gdy zacząłem chodzić do szkoły moja pasywność

32 „Zyg. Hor.”, „Moja autobiografia”, ur. 1912, Zakopane (1934), j. polski, sygn. 3654, w: Cała, Ostatnie, 486.

33 Tamże. 
prys[nę] ia i zacząłem protestować najbardziej wtedy dla mnie dostępnym środkiem - uciekaniem z tej „nory”, która nazywała się chederem ${ }^{34}$.

Najsilniejszym bodźcem było zatem zderzenie realiów szkółki religijnej ze szkołą powszechną. Było to ostateczne przypieczętowanie decyzji o zmianie szkoły:

O ile cheder nie wywoływał u mnie nic miłego, ani też nic przyjemnego, o tyle szkoła od razu, kiedy przystąpiłem jej próg, szarpnęła jakąś wewnętrzną strunę. Same przygotowania, czynione przed pierwszym pójściem do szkoły, były czymś odrębnym, nic wspólnego niemającym z chederem. Z nałożeniem czystej koszuli i szabasowego ubranka (przed pójściem do szkoły) wionął dla mnie jakiś letni, ciepły wietrzyk. Czuło się w tych przygotowaniach ciepłą, głaskającą rękę, tak kontrastowo odmienną od tej, którą podał mi po raz pierwszy „rebe”, gdy przyszedł wprowadzić mnie po raz pierwszy do wnętrza „szkoły” [...] Ciekawe, że nim poznałem tę drugą szkołę, ta pierwsza mnie nie odstraszała. Dopiero, gdy znalazłem się w klasie, gdy po raz pierwszy usiadłem na ładnie wyheblowanej ławce, zrodził się we mnie wstręt i nienawiść do chederu, do jego długich stołów i brudnych ław. Zacząłem stamtąd jak najczęściej uciekać.... ${ }^{35}$.

Mimo oporów rodziców, w wieku ośmiu lat przestał uczęszczać do chederu, ukończył za to siedem klas szkoły powszechnej oraz gimnazjum. Z powodzeniem zdał maturę. Bardzo pragnął pójść na studia, jednak edukacja była ogromnym obciążeniem dla rodziny.

Z kolei młody Żyd o pseudonimie „G.W.” (ur. 1919, blisko Siedlec), rozpamiętywał swój pierwszy dzień w chederze, gdy uświadomił sobie, że stracił dziecięcą wolność. Krótko po rozpoczęciu nauki doszło do przykrego wypadku. Chłopiec rozbił sobie czoło, w skutek czego matka przeniosła go do innej placówki. W tym chederze mełamed był starszym człowiekiem z siwą brodą, surową i groźną twarzą, zdobywającym autorytet za pomocą skórzanego bicza ${ }^{36}$. „G. W.” stał się inicjatorem ucieczki grupy dzieci, które wolały bawić się na zewnątrz. Został za to surowo ukarany, musiał pozostać

34 „EM.TEPA”, „Pamiętnik bezrobotnego inteligenta”, Mojżesz Tendlarz, ur. 1919, Parczew, woj. Lubuskie (1939), j. polski, sygn. 3792, w: Cała, Ostatnie, 209.

35 Tamże.

36 „G.W.”, ur. 1919, (1939), sygn. 3717, jidysz, w: Shandler, Awakening, 299. 
po zajęciach do późnych godzin wieczornych. Był tam „przetrzymywany” mimo głodu i zanoszenia się płaczem ${ }^{37}$.

\section{Egzemplifikacja II}

Zgoła inaczej ułożyła się biografia „Jafeta” (ur. w 1918 roku w Sulejowie). Ten chłopiec wychował się w rodzinie chasydzkiej. Jego edukacja miała charakter stricte religijny: cheder, potem nauka w bejt ha-midraszu, ukończenie akademii talmudycznej. Na każdym etapie edukacji był uczniem wybitnym, co przynosiło radość rodzicom.

Nie bacząc na złą sytuację materialną rodziców, posłano mnie w wieku trzech lat do chederu. Ze swoich skąpych zarobków rodzice musieli zaoszczędzić dwa złote tygodniowo, aby spłacić mełameda. Uczyłem się pilnie i mełamed przystąpił do wprowadzania mnie w tajniki Tory, kiedy osiągnąłem piąty rok życia. W tym bowiem wieku, jak napisane jest w traktacie Tamudu i Pirkej Awot, chłopiec żydowski ma obowiązek przystąpić do nauki Pięcioksięgu. Ojciec widząc, że wykazuję zdolności do nauki, zaczął mnie otaczać większą miłością niż innych członków rodziny. Przed moim pójściem do chederu, na przykład, kupował mi czekoladki i różne zabawki. Do siódmego roku życia uczyłem się u tego samego mełameda. W tym wieku potrafiłem już samodzielnie uczyć się chumesz mit Raszi $i^{38}$.

Jego rodzice również stanęli przed dylematem, czy zapisać syna do szkoły państwowej: „Ojciec oświadczył, że szkoła powszechna to droga do porzucenia wiary żydowskiej (...). Matka odpowiedziała, że nawet jeśli chce się zostać rabinem, to też trzeba opanować język polski" ${ }^{\prime 39}$. W tej biografii pierwszy kontakt z nową szkołą był zdecydowanie inny niż w poprzednich cytowanych życiorysach:

Pierwsze wrażenie było nieprzyjemne. W chederze siedzieliśmy z nakrytymi głowami, a tu podczas lekcji wszyscy siedzieli w ławkach bez czapek. Dotychczas nie uczyłem się razem z dziewczętami, a co dopiero z sziksami. Mimo

37 Tamże, 300.

38 „Jafet”, „Wspomnienia młodego rabina”, ur. 1918, Sulejów (1939), jidysz, sygn. 3782 , w: Cała, Ostatnie, 187-188.

${ }^{39}$ Tamże. 
to myślałem sobie, że będzie dobrze. Trzeba się tylko do tego przyzwyczaić. Porządek szkolny przewidywał zajęcia od godziny pierwszej do piątej po południu. W chederze uczyłem się dalej, od ósmej do jedenastej i od piątej do siódmej wieczorem. Starannie przygotowywałem się do każdej lekcji w chederze. Chciałem, żeby ojciec był ze mnie zadowolony ${ }^{40}$.

Nauka w szkole powszechnej szła „Jafetowi” bardzo dobrze. Szybko opanował język polski, chętnie czytał polskie książki. Popołudniami samodzielnie studiował pisma religijne w bejt ha-midraszu. Po ukończeniu szkoły kontynuował edukację religijną w warszawskiej jesziwie „Metuwta”. Dobrze zapowiadająca się kariera rabinacka jednakże i w tym przypadku została przerwana. Uzyskawszy certyfikat rabinacki, ku rozpaczy rodziców, pod wpływem miłości do córki pracodawcy zgolił brodę oraz pejsy i rozpoczął pracę w fabryce. Duży wpływ na zmianę jego światopoglądu miała również lektura świeckiej literatury oraz nauka w szkole polskiej.

\section{Egzemplifikacja III}

W kilku pamiętnikach odnajdziemy wzmianki na temat chederów zreformowanych. „Abraham Harefuler” (ur. 1921 roku w Warszawie) wywodził się z ubogiej rodziny rzemieślniczej. W dzieciństwie był bardzo religijny, od 3. roku życia uczył się w chederze. Po śmierci matki bardzo szybko musiał podjąć pracę i zostać młodym proletariuszem. W swojej relacji chwalił pierwszą placówkę, do której uczęszczał: „U Hersz-Judla nauczyłem się Chymesz i rasze. Zdaje się, że tref i iwre też się u niego nauczyłem, ale tego nie pamiętam już. Pięcioksiąg Mojżesza był dla mnie pierwszym materiałem umysłowym i duchowym" ${ }^{41}$. Była to szkoła nowoczesna, dobrze wyposażona, prowadząca naukę czytania i pisania po polsku. O ile jednak pierwszy cheder to dla niego „błogie rozczulenie i sentyment”42, o tyle - jak dodaje - potem oddano go do innego, znacznie gorszego chederu:

Rebe z tego chederu nie budzi już we mnie uczuciowych wspomnień. Wspominam go szaro i powszechnie. Nazywał się u nas, dzieci, „Rojter-Boryk” dla

40 Tamże, 188.

${ }^{41}$ „Abraham Harefuler”, „Pamiętnik żydowskiego młodzieńca”, Abraham Rotfarb, ur. 1921, Warszawa (1939), j. polski, sygn. 3598, w: Cała, Ostatnie, 94.

42 Tamże, 102. 
swej mocno czerwonej twarzy, jak burak. W ręku wiecznie trzymał dyscyplinę, zawsze skorą do łajania [...]. Pokój to był ciemny i nieobszerny. Zamiast ławek stał długi stół na kozłach, a z obu stron siedzieli uczniowie. Rebe nie miał oddzielnego miejsca, tylko siedział na końcu stołu, od strony okna. Każdy uczeń, który by zrobił najmniejszy błąd w czytaniu, dostawał dyscypliną po plecach. A trzeba zaznaczyć, że takiego ucznia nie było, co by błędu nie zrobił. Więc nic dziwnego, że dzień spędzony na wagarach był szczęśliwszy niż pobyt w chederze. Taka nauka stała się dla mnie jarzmem ${ }^{43}$.

Częściowo pozytywne doświadczenie edukacji chederowskiej miał „S. Etonis” (ur. w 1910 w miasteczku blisko Mińska). W pierwszym chederze mełamed, dostrzegając jego zdolności umysłowe, wyróżniał młodego adepta i dbał o jego rozwój intelektualny. Drugi cheder był placówką zreformowaną, gdzie:

Nauczyciel, miejscowy młodzieniec, był «postępowy». Uczył nas czytać i pisać po hebrajsku z podręcznika, nie gorzej niż recytowania modlitw. Nie siedzieliśmy na stołach, lecz w prawdziwych szkolnych ławkach. Oczywiście, były tam hebrajskie piosenki, takie jak Mały Pokój, Śpij moje dziecko, Matko, Matko, inne dziecięce piosenki, i na koniec zawsze śpiewaliśmy Hatikwę ${ }^{44}$.

Kolejna placówka przyniosła jednak rozczarowanie. Twórca pamiętnika opisuje strajk niezadowolonych uczniów, wywołany brakiem kompetencji dydaktycznych nauczyciela. Ostatecznie rodzice wspólnie podjęli decyzję o zwolnieniu mełameda i poszukali nowego, który uczył dzieci nowoczesnego hebrajskiego i okazał się ekspertem $\mathrm{w}$ gramatyce ${ }^{45}$. Autor wspomina jeszcze jednego nauczyciela, uwielbianego przez dzieci, potrafiącego zainspirować na tyle, że uczniowie zostawali w chederze dłużej po lekcjach ${ }^{46}$. „S. Etonis” dzięki zaangażowaniu i zdolnościom skończył jesziwę i został nauczycielem religii. W zakończeniu biografii podaje jednak, że zdecydował nie zostawać rabinem. Chciał bowiem poszerzyć swoje horyzonty i skończyć gimnazjum w Wilnie.

Pilnym adeptem był również „Stormer” (ur. 1917 w Opocznie, w pobożnej, chasydzkiej rodzinie). W pamiętniku pisał o sobie, że był dobrym

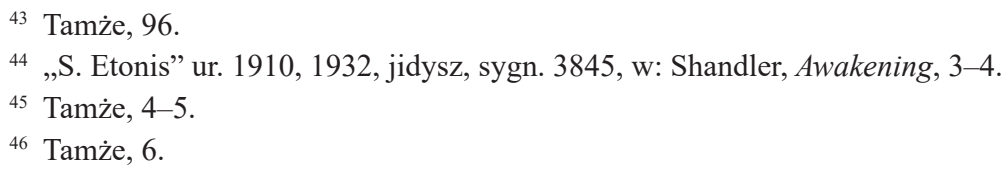


uczniem chederu. Nie uciekał tak jak inni, a wręcz przeciwnie - zawsze przychodził do placówki jako pierwszy i wychodził z niej ostatni. Po śmierci ojca przeniósł się do Łodzi, gdzie miał okazję uczęszczać na nauki do bejt-hamidrasz, potem przez dwa lata do nowoczesnego chederu z językiem polskim (Jesodej ha-Tora), gdzie z powodzeniem kończył kolejne etapy nauki (równolegle ucząc się w szkole powszechnej) ${ }^{47}$. Ten autor również kontynuował naukę w jesziwie. Niestety, złe warunki finansowe zmusiły go do podjęcia pracy fizycznej w młodym wieku.

\section{Podsumowanie}

Przytoczone wypowiedzi pamiętnikarskie w większości przypadków potwierdzają dość powszechną opinię na temat niskiego poziomu nauczania w chederach. Retrospektywnie szkółki postrzegane były przez młodzież przede wszystkim jako instytucje odbierające radość dzieciństwa. Wiele zależało także od indywidualnych cech osobowościowych nauczycieli. Raczej spójne, niepochlebne narracje odnoszą się głównie do chederów starego typu. Krytyce poddawano zarówno styl nauczania, warunki nauki w domu mełameda i bardziej ogólnie sensowność tradycyjnej edukacji religijnej (Egzemplifikacja I). We wspomnieniach pamiętnikarskich druzgocącej krytyce poddawany jest system dydaktyczny, szczególnie w zderzeniu z późniejszą edukacją w szkole powszechnej. Lilientalowa również wspominała, że metoda szkolna szwankuje ,jako że do nauczania dziatwy biorą się jednostki do niczego niezdolne i nieoświecone. Stąd «mełamed» stał się symbolem niedołęgi i stosunek do niego cechuje pewien odcień pogardy" ${ }^{48}$. Z kolei działacz CISZO, Szlomo Mendelsohn, zwracał uwagę na mechaniczne nauczanie poprzez ciągłe powtarzanie wybranych fragmentów religijnych, gdzie ,rezultatem nauki jest albo szkodliwa jednostronność, albo zupełna tępota umysłowa" ${ }^{49}$.

Historyk i socjolog Kamil Kijek przekonuje, że w narracjach autorów tychże pamiętników cheder był instytucją, która miała największy wpływ na ich dzieciństwo, stanowiąc symbol wartości poprzednich pokoleń. Była to forma edukacji najpowszechniej krytykowana, synonim kryzysu bądź

47 „Stormer” ur. 1917, 1939, jidysz, sygn. 3707, w: Shandler, Awakening, 227.

${ }^{48}$ Lilientalowa, Dziecko, 85.

49 Szlomo Mendelsohn, Nowa szkoła żydowska, czem jest i do czego dąży (Warszawa: Wydawnictwo Szkoła i Życie, 1924), 27-28. 
upadku świata tradycji i religii ${ }^{50}$. Jednocześnie narracja ta korespondowała z krytyką ze strony opcji jidyszystycznej i socjalizującej sieci CISZO, hebrajskiego Tarbutu oraz środowiska JIWO ${ }^{51}$. Nie dziwią zatem tak szczere i otwarte wystąpienia młodzieży przeciwko szkolnictwu religijnemu starego typu. Kijek pisze dalej:

Raziła ich materialna mizeria chederu i jego otoczenia, przekazywana w nich ezoteryczna i nikomu niepotrzebna wiedza, wreszcie przemoc, ignorancja i brak pedagogicznego podejścia uczących mełamedów. Dla dorastających w okresie międzywojennym młodych ludzi cheder był „murem getta” w stopniu nie mniejszym niż dla XVIII- i XIX-wiecznych luminarzy haskali. Podobnie jak oni, dorastająca w latach trzydziestych XX wieku młodzież marzyła o świeckim wykształceniu ${ }^{52}$.

Z pamiętników dowiadujemy się, że w chederach panowały złe warunki dla nauki, bowiem szkoły mieściły się najczęściej w domu mełameda i zajmowały jedną izbę lub dzieliły pomieszczenie $\mathrm{z}$ rodziną nauczyciela. Potwierdzają to również inne źródła. Z Księgi Pamięci miasta Włodawy wynika na przykład, że:

Meble w chederze stanowił zwykły stół z surowego drzewa, który niegdyś był biały, ale z tej bieli mało, co zostało. Stół był zaplamiony atramentem, porysowany, posiadał „blizny” po dziecięcych scyzorykach. Wzdłuż stołu stały dwie długie ławki, które kiwały się, gdyż nigdy nogi nie były równe, zawsze jedna noga była wyższa lub niższa. Naprzeciwko rebego stała ława do spania, zbita z długiej skrzyni, a pośrodku leżały sienniki, worki nabite twardą słomą. Górna część zbita była z 2-3 desek. Za dnia ława ta służyła jako siedzenie dla uczniów, nocą zastępowała łóżko dla domowników rebiego ${ }^{53}$.

${ }^{50}$ Tezę tę potwierdzają również analizy innych pamiętników ze zbiorów Archiwum JIWO w Nowym Jorku, niepublikowane w cytowanych przeze mnie zbiorach A. Cały i J. Shandlera. Szerzej: Kamil Kijek, Dzieci modernizmu. Świadomość, kultura i socjalizacja polityczna młodzieży żydowskiej w II Rzeczypospolitej (Wrocław: Wydawnictwo Uniwersytetu Wrocławskiego, 2017), 53-58. Kijek w rozważaniach na temat edukacji w chederach tradycyjnych uwzględnił autobiografie o następujących numerach sygnatur: 3591, 3726, 3571, 3571, 3770, 3561, 3507, 3663, 3861, 3598, 3845.

${ }^{51}$ Kijek, Dzieci, 53-54.

52 Tamże, 55.

${ }^{53}$ Fragmenty „Księgi Pamięci Włodawy i Okolic”, http://muzeumwlodawa.pl/index.php/ wystawy-stale/361-w-pokoju-melameda (dostęp: 30.11.2017). 
Interesujących danych na temat funkcjonowania placówek religijnych dostarcza także ankieta Cekabe (Centrali Kas Bezprocentowych) z 1935 roku. W chederach prywatnych uczyło się przeciętnie po 17 chłopców, natomiast w społecznych Talmud-Torach - nawet 58. Dwie trzecie chederów mieściło się w prywatnych mieszkaniach mełameda, w tym $40 \%$ pokój nauki to również izba, w której mieszkał nauczyciel. Ponad połowa mełamedów miała powyżej 50 lat, natomiast $37 \% \mathrm{z}$ nich całe życie poświęciło nauczaniu ${ }^{54}$.

Nauczyciel szkoły religijnej jawi się w diariuszach jako autorytet narzucony, surowy belfer i niekompetentny, niesprawiedliwy dydaktyk. Jest pedagogiem zapamiętanym, aczkolwiek w negatywnych odcieniach reminiscencji - często mglistych już - okresu wczesnego dzieciństwa. Przed wprowadzeniem reformy z 1919 roku praca mełameda nie wymagała wysokich kwalifikacji. Zajmowały się nią osoby, które nie odnalazły się w szerszym systemie zatrudnienia. Bardziej utalentowani członkowie społeczności trudnili się handlem lub podążali drogą kariery religijnej (rabin, sędzia w sądzie rabinackim, tudzież nauczyciel w jesziwie). Niskie zarobki pracownicy szkółek starali się zrekompensować zwiększeniem liczby uczniów, a to z kolei powodowało przepełnienie chederów. W okresie kryzysu gospodarczego niektórzy Żydzi tracili swoje posady i czasowo zatrudniali się jako mełamedzi, a to również nie sprzyjało jakości kształcenia w tym zawodzie ${ }^{55}$.

$\mathrm{Z}$ relacji pamiętnikarskich wynika, że mełamedzi nie stronili od kar cielesnych, przemocy fizycznej i poniżania uczniów. Pierwszego dnia w chederze witano dziecko cukierkami, później dominował już system nagan. Do najpopularniejszych wedle Lilientalowej należało: zakładanie rondla na głowę i stanie w kącie z miotłą w ręku. Co ciekawe ,uczniowie nieraz mścili się za zniewagę i gdy na przykład mełamed zasnął pochylony, lakiem brodę do stołu mu przyklejali, a dziś, chociaż o wielu dawnych karach nie słychać, razy pozostały i nadal płatają chłopcy złośliwe figle swoim «mistrzom»"56.

Można jednakże zauważyć, że nie wszystkie wspomnienia są krytyczne. Przypadek ,Jafeta” jest wyjątkowy, zasługujący na wyróżnienie w odrębnej kategorii (Egzemplifikacja II). Ten bardzo zdolny i pilny uczeń pozytyw-

${ }^{54}$ Łącznie ankieta objęła 210 miast. Największa liczba chederów funkcjonowała w tzw. byłej Kongresówce (117). Około 70\% uczniów było w wieku 7-14 lat, 29\% miało mniej niż 7 lat, 1\% - stanowili chłopcy w wieku ponad 14 lat. „Chedery w Polsce według ankiety Cekabe (Centrali Kas Bezprocentowych) z 1935 r.”, w: Dzieje Żydów w Polsce. 1918-1939. Wybór tekstów źródłowych, red. Rafał Żebrowski (Warszawa: Żydowski Instytut Historyczny, 1993), 111.

55 Por. Zalkin, „Heder”.

${ }^{56}$ Lilientalowa, Dziecko, 88. 
nie wspomina okres edukacji w chederze. Nigdy nie przysparzał kłopotów szkolnych swoim nauczycielom ani rodzicom, a w mieście uznawany był za idealnego kandydata na rabina. Przeżył swoisty „szok kulturowy”, gdy rozpoczął naukę w szkole powszechnej, lecz szybko opanował nowe przedmioty i nawiązał kontakty z rówieśnikami. Pomimo wielkich predyspozycji oraz zaangażowania rodziców zrezygnował z identyfikacji i kariery religijnej, co pokazuje, jak silne były wówczas nowe treny społeczne w kulturze żydowskiej.

Chedery przez wieki odpowiadały na wymagania społeczności religijnej, zapewniały gruntowne, pamięciowe opanowanie pism religijnych oraz całodzienną opiekę. Borzymińska przypomina, iż pomimo negacji ze strony środowisk postępowych, chedery pielęgnowały tożsamości religijną i narodową Żydów rozproszonych w diasporach, a przede wszystkim przyczyniły się do wysokiego poziomu alfabetyzacji tej społeczności ${ }^{57}$. Liczne, urozmaicone zabawy dydaktyczne ${ }^{58}$ oraz nauczanie pamięciowe powodowało, że dzieci, które kontynuowały naukę w szkole polskiej, radziły sobie w niej bardzo dobrze (mimo często początkowej nieznajomości języka polskiego). Dla kilku autorów pamiętników edukacja w chederze stanowiła ważny krok do kontynuacji kształcenia na wyższym poziomie, często w znamienitych jesziwach (Egzemplifikacja II i III).

Autorzy znacznie lepiej oceniali swoje doświadczenia edukacyjne w chederach nowego typu, w których postać mełameda jako nowoczesnego dydaktyka burzy homogenicznie negatywny wizerunek. Z dużą aprobatą wśród młodzieży spotyka się nauczanie przedmiotów świeckich (szczególnie języka polskiego) i nowoczesne wyposażenie placówek (Egzemplifikacja III) ${ }^{59}$. W trzeciej ilustracji młodzi Żydzi mieli do czynienia z różnymi formami edukacji religijnej pierwszego stopnia, nieraz kilkukrotnie zmieniali placówki szkolne, stąd ich bagaż edukacyjny jest bogatszy od biografii „Jafeta”.

Interesującym wątkiem, wymagającym dalszych badań, wydaje się być wpływ rodziców na zmiany w szkolnictwie religijnym. Z pamiętników wynika bowiem, że rodzice mniej lub bardziej intencjonalnie próbowali „reformo-

57 Borzymińska, Szkolnictwo, 70.

58 Wiele interesujących zabaw dydaktycznych opisuje w swojej książce Lilientalowa, Dziecko, 96-108.

59 Tezę tę potwierdzają również analizy innych pamiętników ze zbiorów Archiwum JIWO w Nowym Jorku, niepublikowane w cytowanych przeze mnie zbiorach A. Cały i J. Shandlera. Są to autobiografie o sygnaturach: 3718, 3591, 3623, 3542, 3561, 3508, 3591. Szerzej: Kijek, Dzieci, 154-164. 
wać" edukację religijną, niejako wymuszając ulepszenia poprzez częste zmiany placówek dla swoich dzieci bądź decydując o paralelnej nauce w szkole powszechnej ${ }^{60}$. Szczególną rolę $\mathrm{w}$ tym zakresie odegrały matki, świadome wyzwań cywilizacyjnych i nieuchronności edukacji świeckiej w polskim systemie szkolnictwa. Przy czym należy zwrócić uwagę, że ta druga opcja wymuszana była także przez niespełnianie obowiązku szkolnego przez większość chederów, jak i przez samych młodych adeptów - ich ucieczki, płacz oraz naiwny (choć gwałtowny) dziecięcy sprzeciw.

\section{Cheders and Melameds in the Memories of Young Jews from the Inter-War Period (Summary)}

The article attempts to create a collective portrait of cheders and teachers working in them (melameds) during the inter-war period. Education in cheders was an extremely important stage of development for Jewish boys. It determined their further educational and professional careers and prepared them for full participation in Jewish communities. These issues are analysed based on the works of historians and diaries using the method of exemplification. The analysis includes autobiographies of young Polish Jews from the inter-war period from the collections of the YIVO Institute for Jewish Research in New York. The article also tries to show the process of changes within religious education, the main reasons for attacks at traditional schools and attempts to reform them. The image of cheders conveyed in diaries is part of this critical trend, but it is not homogeneous. Definitely more positive accounts can be found in the diaries of young Jews who attended reformed cheders.

Keywords: cheder; melamed; diaries; inter-war period.

\section{Cheder i melamed we wspomnieniach młodzieży żydowskiej okresu międzywojennego (Streszczenie)}

Artykuł stanowi próbę stworzenia zbiorowego portretu chederów oraz pracujących w nich nauczycieli (mełamedów) w okresie dwudziestolecia międzywojenne-

${ }^{60}$ Równolegle w chederach i szkołach publicznych uczyli się także m.in.: „S.B” (sygn. 3648, ur. 1917, napisane w 1939 r., jidysz); „M.M.D” (sygn. 3651, ur. 1913, 1934, jidysz); 
go. Edukacja w chederze stanowiła niezwykle ważny etap na drodze do dorastania żydowskich chłopców, decydujący o dalszych trajektoriach edukacyjnych i zawodowych, przygotowujący do pełnego uczestnictwa we wspólnocie. Bazą dla analizy tego zagadnienia są prace historyków, a także materiały pamiętnikarskie: z zastosowaniem metody egzemplifikacji. Analizie poddano autobiografie polskiej młodzieży żydowskiej okresu międzywojennego ze zbiorów YIVO Institute for Jewish Research w Nowym Jorku. Starano się także pokazać proces przemian w obrębie szkolnictwa religijnego, główne powody ataków kierowanych wobec tradycyjnych szkółek oraz podejmowane próby ich reformowania. Przekazany we wspomnieniach obraz chederów wpisuje się w ten krytyczny nurt, ale nie jest jednorodny. Zdecydowanie bardziej pozytywne relacje pojawiają się w diariuszach młodych Żydów, którzy uczęszczali do chederów zreformowanych.

Słowa kluczowe: cheder; mełamed; pamiętniki; dwudziestolecie międzywojenne.

\section{Bibliografia}

Borzymińska, Zofia. Szkolnictwo żydowskie w Warszawie 1831-1870. Warszawa: Żydowski Instytut Historyczny - Instytut Naukowo-Badawczy, 1994.

Cała, Alina. Ostatnie pokolenie. Autobiografie polskiej młodzieży żydowskiej okresu międzywojennego ze zbiorów YIVO Institute for Jewish Research w Nowym Jorku. Warszawa: „Sic!”, 2003.

„Chedery w Polsce wedhug ankiety Cekabe (Centrali Kas Bezprocentowych) z 1935 r.". W: Dzieje Żydów w Polsce. 1918-1939. Wybór tekstów źródtowych, red. Żebrowski Rafał, 111. Warszawa: Żydowski Instytut Historyczny, 1993.

Chmielewski, Samuel. „Stan szkolnictwa wśród Żydów w Polsce”. Sprawy Narodowościowe 1-2 (1937): 32-74.

Cukras-Stelągowska, Joanna. „Biograficzna wspólnota wspomnień «Ostatniego pokolenia» - młodzież żydowska wobec dylematów tożsamościowych". Paedagogia Christiana 32 (2014): 185-202.

Cukras-Stelągowska, Joanna. „Od chederu do jesziwy w polskiej diasporze - dwustopniowy system żydowskiego szkolnictwa religijnego i jego współczesne transformacje". Paedagogia Christiana 23 (2009): 121-135.

„E. M” (sygn. 3652, ur. 1912, 1934, j. polski); „P. S” (sygn. 3671, ur. 1912, 1934, j. polski); „R.A” (sygn. 3669, ur. 1913, 1934, j. polski).; „S.P” (sygn. 3573, ur. 1915, 1934, jidysz); „M.M” (sygn. 3802, ur. 1916, 1934, jidysz). Pamiętniki dostępne w archiwum CAHJP w Jerozolimie. 
Cukras-Stelągowska, Joanna. „Upbringing Styles In an Orthodox Jewish Family In the Interwar Period. Autobiographical Contexts". Studienreihe der Polnischen Historischen Mission 2 (2015): 149-168.

Daniłowicz, Barbara. ,Jutrzenka - tygodnik dla Izraelitów”. W: Studia o szkolnictwie i oświacie mniejszości narodowych w XIX i XX wieku, red. Stefania Walasek, 23-62. Wrocław: Wydawnictwo Uniwersytetu Wrocławskiego, 1994.

Giza, Anna. „Biografia jako fakt empiryczny i jako kategoria teoretyczna”. W: Metoda biograficzna w socjologii, red. Jan Włodarek, Marek Ziółkowski, 39-54. Warszawa-Poznań: Państwowe Wydawnictwo Naukowe, 1990.

Hellwig, Jan. „Edukacja młodzieży żydowskiej w XIX w. w Poznaniu”. W: Rola mniejszości narodowych w kulturze i oświacie polskiej w latach 1700-1939, red. Aleksandra Bilewicz, Stefania Walasek, 117-122. Wrocław: Wydawnictwo Uniwersytetu Wrocławskiego, 1998.

Hertzberg, Arthur, Aron Hirt-Manheimer. Żydzi. Istota i charakter narodu. Warszawa: Mada, 2001.

Hoffman, Zygmunt. „Od chederu do jesziwy”. Kalendarz Żydowski (1985/86): 84.

Jagodzińska, Agnieszka, Marcin Wodziński. Izraelita, 1866-1915. Wybór źródet. Kraków: Wydawnictwo Austeria, 2015.

Kijek, Kamil. Dzieci modernizmu. Świadomość, kultura i socjalizacja polityczna młodzieży żydowskiej w II Rzeczypospolitej. Wrocław: Wydawnictwo Uniwersytetu Wrocławskiego, 2017.

„Księga Pamięci Włodawy i Okolic”. http://muzeumwlodawa.pl/index.php/wystawy-stale/361-w-pokoju-melameda (dostęp: 30.11.2017).

Lilientalowa, Regina. Dziecko żydowskie. Warszawa: Stowarzyszenie Midrasz, 2007. Lisek, Joanna. „Sara Szenirer - Matka Bejs Jakow”. Cwiszn 2/3 (2014): 67.

Mauersberg, Stanisław. Szkolnictwo powszechne dla mniejszości narodowych w Polsce w latach 1918-1939. Wrocław-Warszawa-Kraków: Zakład Narodowy im. Ossolińskich, 1968.

Mendelsohn, Szlomo. Nowa szkoła żydowska, czem jest i do czego dąży. Warszawa: Wydawnictwo Szkoła i Życie, 1924.

Papierowski, Andrzej Jerzy. ,Żydowskie szkolnictwo religijne na przykładzie działalności prywatnej ortodoksyjnej szkoły Isoda Tora (Podstawy Tory) w Płocku (1921-1939)". Notatki Płockie 4 (2012): 27-37.

Renz, Regina. „Wychowanie w rodzinie żydowskiej w Polsce międzywojennej”. W: Rola mniejszości narodowych w kulturze i oświacie polskiej w latach 1700-1939, red. Aleksandra Bilewicz, Stefania Walasek, 245-254. Wrocław: Wydawnictwo Uniwersytetu Wrocławskiego, 1998.

Shandler, Jeffrey. Awakening Lives. Autobiographies of Jewish Youth in Poland before Holocaust. New Haven: Yale University Press, 2002. 
Szczepański, Jan. Odmiany czasu teraźniejszego. Warszawa: Książka i Wiedza, 1973. Szczerbiński, Waldemar. „Charakterystyka kultury żydowskiej w Izraelu i przejawy jej sekularyzacji”. Teologia i Człowiek 27 (2014): 79-107.

Webber, Jonathan. „Współczesne tożsamości żydowskie”. W: Sytuacja mniejszościowa i tożsamość, red. Zdzisław Mach, Andrzej Paluch, 144-150. Kraków: Uniwersytet Jagielloński, 1992.

Winiarz, Adam. „Sprawa rządowego szkolnictwa elementarnego dla dzieci żydowskich w Księstwie Warszawskim i Królestwie Polskim (1807-1831)". W: Studia o szkolnictwie i oświacie mniejszości narodowych w XIX i XX wieku, red. Stefania Walasek, 7-22. Wrocław: Wydawnictwo Uniwersytetu Wrocławskiego, 1994.

Żebrowski, Rafał. „Polski Słownik Judaistyczny”. http://www.jhi.pl/psj/ (dostęp: 15.11.2017).

Żebrowski, Rafał. Dzieje Żydów w Polsce. 1918-1939. Wybór tekstów źródlowych. Warszawa: Żydowski Instytut Historyczny, 1993. 
